\title{
Novel synthesis of quinazolino[3,2-a][1,5]benzodiazepines: an experimental and computational study
}

\author{
Regina Janciene, ${ }^{a}$ Tomas Javorskis, ${ }^{a}$ Gema Mikulskiene, ${ }^{* a}$ Ausra Vektariene, ${ }^{b}$ \\ Gytis Vektaris, ${ }^{b}$ and Kazimieras Algirdas Klimavicius ${ }^{a}$ \\ ${ }^{a}$ Vilnius University Institute of Biochemistry, Mokslininku 12, LT-08662 Vilnius, Lithuania \\ ${ }^{b}$ Vilnius University Institute of Theoretical Physics and Astronomy, A. Gostauto 12, \\ LT-01108 Vilnius, Lithuania \\ E-mail: gema.mikulskiene@bchi.vu.lt
}

DOI: http://dx.doi.org/10.3998/ark.5550190.p009.141

\begin{abstract}
5-Substituted 7-methyl-6,7-dihydroquinazolino[3,2-a][[1,5]benzodiazepin-13(5H)-one derivatives were synthesized in a one-step sequential acylation-cyclization reaction with a simple procedure from an appropriate 5-substituted 3-methyl-1,3,4,5-tetrahydro-2 $\mathrm{H}$-1,5-benzodiazepin2-one and 2-sulfinylaminobenzoyl chlorides. The mechanism of the heterocyclization reaction was studied by the DFT method using the B3LYP functional and 6-31+G(d, p) basis set.
\end{abstract}

Keywords: Fused quinazolines, 1,5-benzodiazepines, 2-sulfinylaminobenzoyl chloride, DFT calculations, quantum chemistry

\section{Introduction}

Benzodiazepines constitute an important class of psychopharmaceuticals due to their broad range of activities, in particular as tranquilizers, and they also have a traditional place in antiepileptic therapy. ${ }^{1,2}$ Moreover, benzodiazepines are effective as nonnucleoside inhibitors of HIV-1 reverse transcriptase. ${ }^{3}$ Therefore, the benzodiazepine nucleus is a well-studied pharmacophoric scaffold that has emerged as a core structure unit of various biological activities and the research in this area is very active. ${ }^{4}$ It is well documented that the pharmacological activity could be increased when an additional heterocyclic ring is fused to the heptatomic diazepine nucleus. ${ }^{5}$ Thus, considerable attention has been directed towards the synthesis of polycyclic 1,4-benzodiazepines, as well as the 1,5-isomers. ${ }^{6}$ Recently, many novel compounds containing heterocyclic ring systems such as triazole, thiazole, imidazole, quinoline, oxadiazole, pyran, oxazole, furan and pyrimidine annelated to the bicyclic 1,5-benzodiazepine have been synthesized by our $^{7-12}$ and other research groups. ${ }^{6,13,14}$ Fused quinazolinones are important heterocyclic compounds with 
widespread occurrence in alkaloids possessing diverse biological activity. ${ }^{15}$ Various methods for the synthesis of these alkaloids encompassing a quinazolino[1,4]benzodiazepine moiety in their skeleton have been developed and numerous research papers have recently appeared. ${ }^{16,17}$

As part of our current studies on the development of efficient methods for the preparation of polycyclic 1,5-benzodiazepines we investigated the synthesis of quinazolino[1,5]benzodiazepines. ${ }^{18,19} \mathrm{~A}$ wide range of novel 6,7-dihydroquinazolino[3,2-a][1,5]benzodiazepinone derivatives were synthesized in a two-step method involving (i) benzoylation of variously substituted 1,3,4,5-tetrahydro-1,5-benzodiazepin-2-ones with 2-nitrobenzoyl chloride, and (ii) a metal induced reductive N-heterocyclization of the obtained 2-nitrobenzoylamides. Although this method displayed notable advantages, such as mild reaction and simple operation, it is not suitable unfortunately for the transformation of appropriate 3-methyl substituted 1-(2nitrobenzoyl)-1,5-benzodiazepinone derivatives. Herein we report a novel procedure for the synthesis of 7-methyl-6,7-dihydroquinazolino[3,2-a][1,5]benzodiazepinones from 5-substituted 3-methyl-1,5-benzodiazepin-2-one derivatives.

Also in this article, the quantum chemical analysis of acylation-cyclization reaction mechanism is presented by calculation of reaction stationary points: reactants $(\mathbf{R})$, products $(\mathbf{P})$, intermediates $(\mathbf{I})$ and transition states $(\mathbf{T})$ on the reaction potential energy profile. ${ }^{20,21}$ Calculations of the intrinsic reaction coordinates (IRC) allow evaluate electron density changes along the reaction progress in the transformation from reactant to the final product. The most probable acylation-cyclization pathway is discussed in detail in the present study. Moreover, the variations of charge, bond order, and bonding character transformations on the reaction progress have been investigated.

\section{Results and Discussion}

\section{Synthetic studies}

In our previous works, the preparation of quinazolino[3,2-a][1,5]benzodiazepine derivatives $\mathbf{3}$ was achieved using the above-mentioned strategy which is shown in Scheme 1. Various 5- ${ }^{3}$ (alkyl, acyl)-4- $\mathrm{R}^{2}\left(\mathrm{H}, \mathrm{CH}_{3}\right)-3-\mathrm{R}^{1}\left(\mathrm{H}, \mathrm{CH}_{3}\right)-1,3,4,5$-tetrahydro-2H-1,5-benzodiazepin-2-ones $\mathbf{1}$ were used as starting materials.

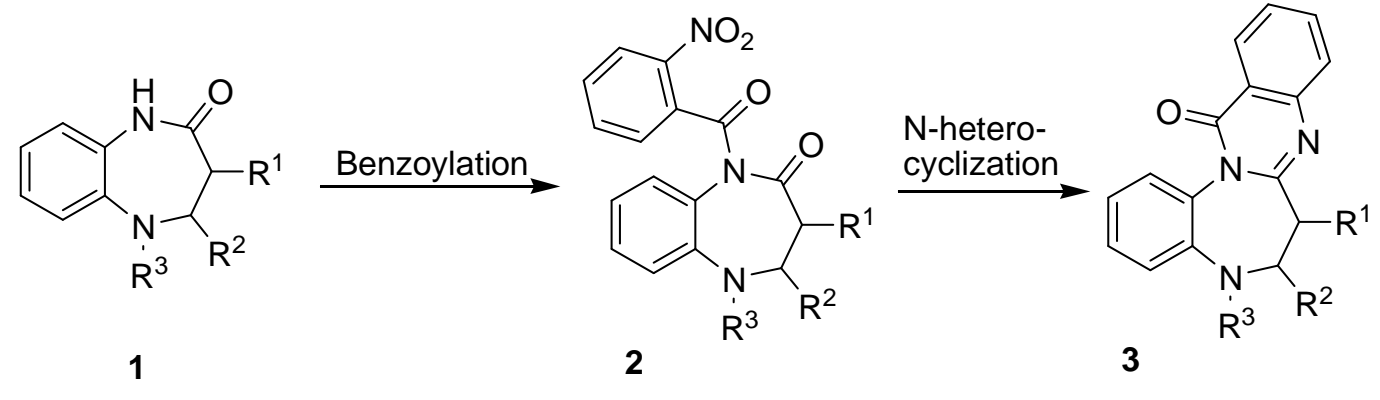

Scheme 1. Synthesis of quinazolino[3,2-a][1,5]benzodiazepines 3 by reductive cyclization. 
In the course of these studies it was established that 3-methyl substituted 1-(2-nitrobenzoyl)amides $2\left(\mathrm{R}^{1}=\mathrm{CH}_{3}\right)$ did not cyclize under the reductive $\mathrm{N}$-heterocyclization conditions and the appropriate tetracyclic 1,5-benzodiazepine derivatives were not formed. A theoretical computational investigation of the cyclization reaction mechanism revealed that the presence of substituents in a diazepine ring causes changes in the electron population of the frontier molecular orbitals. The presence of the electron donating 3-methyl substituent decreased the electrophilicity of the carbon $\mathrm{C}(2)$ atom of the heterocyclic $\mathrm{C}=\mathrm{O}$ group, evoking thus the resistance for further intermolecular rearrangements. ${ }^{18,19}$ This exclusive behavior of starting 3methylsubstituted compounds prompted us to develop an effective synthetic method for the construction of polycyclic 1,5-benzodiazepine derivatives.

Our intention to benzoylate starting compounds $\mathbf{1}$ with N-protected anthranilic acid chloride to prepare appropriate 2-aminobenzoylamides instead of derivatives 2 was not implemented. For example, the interaction of $N$-trifluoroacetylanthranilic acid with thionyl chloride led to the cyclic 3,1-benzoxazin-4-one derivative. ${ }^{22}$

A new approach to the synthesis of the title compounds is shown in Scheme 2. It is based on the use of the activated form of anthranilic acid, 2-sulfinylaminobenzoyl chloride (4). ${ }^{23}$

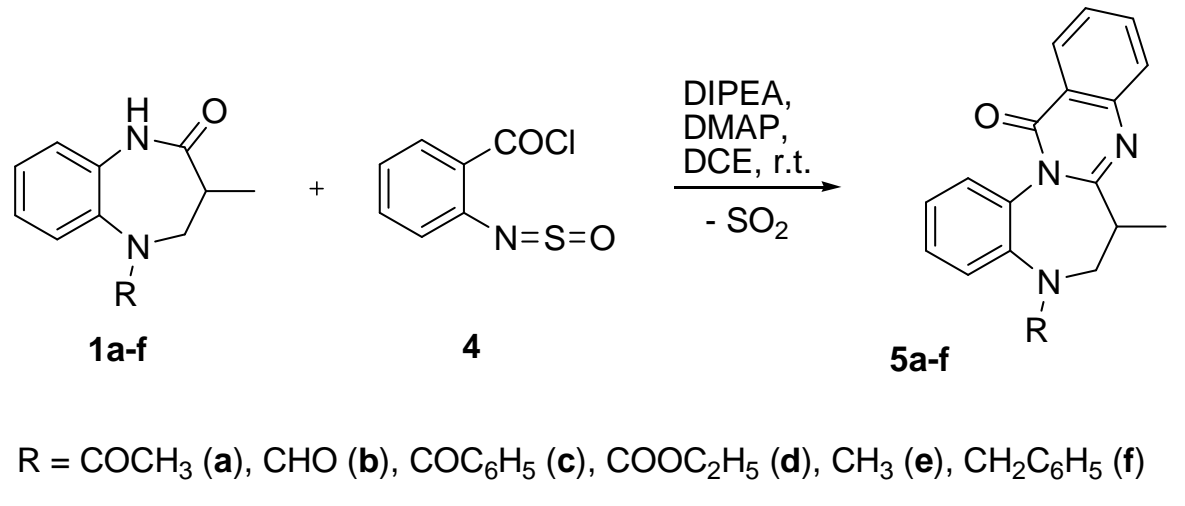

Scheme 2. Synthesis of 7-methyl-6,7-dihydroquinazolino[3,2-a][1,5]benzodiazepin-13-ones 5a-f.

The high reactivity of this reagent towards imines, amides and amines allows its use in the synthesis of various compounds. ${ }^{24}$ Chloride $\mathbf{4}$ was prepared by refluxing anthranilic acid with 10fold excess of thionyl chloride in dry benzene. After completion of the reaction (until reaction mixture turns clear, $\sim 2 \mathrm{~h}$ ), benzene and unreacted thionyl chloride were removed in vacuum and the residual oil was used in the following experiments without additional purification. 5Substituted 3-methyl-1,3,4,5-tetrahydro-2H-1,5-benzodiazepin-2-ones 1a-f were treated with freshly prepared chloride 4 in the presence of $N, N$-diisopropylethylamine (DIPEA) and a catalytic amount of 4-dimethylaminopyridine (DMAP) in dry dichloroethane (DCE) at room temperature. 
This 1-N-acylation process was accompanied by simultaneous $\mathrm{N}$-heterocyclization leading to the 7-methyl-6,7-dihydroquinazolino[3,2-a][1,5]benzodiazepinones 5a-f in 50-75\% yield. Quinazolino[1,5]benzodiazepine derivatives described previously ${ }^{18}$ were also synthesized using this method. For example, treatment of 5-acetyl- and 5-acetyl-4-methyl-1,3,4,5-tetrahydro- $\mathrm{H}$ 1,5-benzodiazepin-2-ones with 2-sulfinylaminobenzoyl chloride led to 5-acetyl- and 5-acetyl-6methyl-6,7-dihydroquinazolino[3,2-a][1,5]benzodiazepin-13(5H)-ones in $65 \%$ and $77 \%$ yields, respectively. Whereas the use of reductive cyclization reaction, provided these compounds in lower yields (45-57\%). ${ }^{18}$ It should be noted that during this cyclofunctionalization reaction the formation of the intermediate acylation products, $1-N$-benzoylamides, was not observed (TLC). We also found that the corresponding 2-sulfinylaminobenzoyl chlorides could be prepared from ring-substituted anthranilic acids such as 6-chloro- and 5-bromoanthranilic acids. 5-Acetyl-3methyl-1,3,4,5-tetrahydro- $2 H$-1,5-benzodiazepine 1a was treated with these reactants under analogous conditions and the corresponding quinazolino[3,2-a][1,5]benzodiazepinones 8 and 9 were synthesized (Scheme 3).

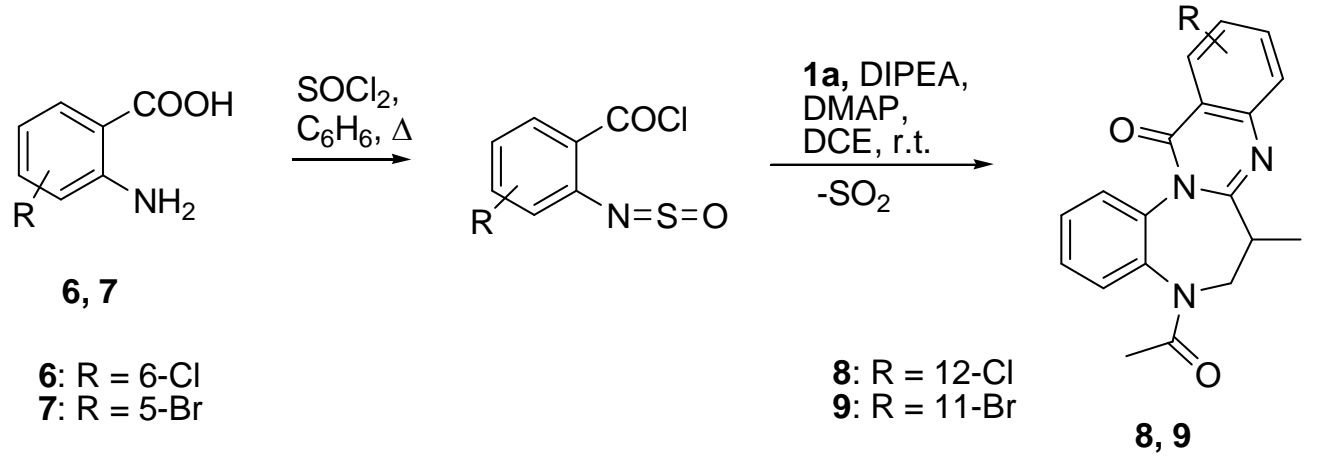

Scheme 3. Synthesis of 5-acetyl-11-bromo(or 12-chloro)-7-methyl-6,7-dihydroquinazolino$[3,2-a][1,5]$ benzodiazepine-13-ones 8 and 9.

The structures of all synthesized compounds were characterized by elemental analysis, IR, ${ }^{1} \mathrm{H}$ and ${ }^{13} \mathrm{C}$ NMR spectra.

The IR spectra of quinazolinobenzodiazepines 5a-f, 8 and 9 show two (5a-d, 8 and 9 ) or one (5e,f) typical bands in the region of the carbonyl group at $1654-1706 \mathrm{~cm}^{-1}$ and $\mathrm{C}=\mathrm{N}$ bond absorption peak at $1608-1619 \mathrm{~cm}^{-1}$.

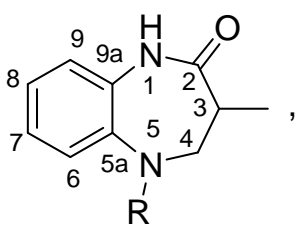

A

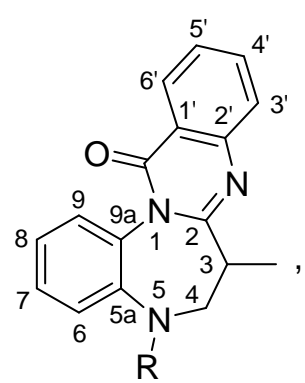

B

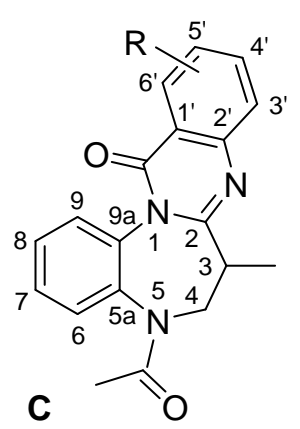

C

Figure 1. The arbitrary numbering of atoms common for all study compounds $\mathbf{1 d}, \mathbf{5 a - f}, \mathbf{8}, \mathbf{9}$. 
The assignment of the NMR spectral lines was carried out using the substituents additivity rules, signal intensities, multiplicities, and NMR data of structurally related compounds. ${ }^{18,19}$ Carbon atoms are marked arbitrarily in the Figure 1 (A- for compound 1d, B-for compounds 5a$\mathbf{f}$, and $\mathbf{C}$ - for compounds $\mathbf{8 , 9}$ ) for easier comparison and systematization of obtained data which are presented in the Experimental section.

Starting compounds 1a-f showed characteristic resonances of the $\mathrm{NH}$ group proton in region of 8.1-8.8 ppm and of the CO group carbon at $173.5-176.0 \mathrm{ppm}$ in ${ }^{1} \mathrm{H}$ and ${ }^{13} \mathrm{C}$ NMR spectra, respectively. The disappearance of these resonances in the NMR spectra suggested the formation of compounds $\mathbf{5 a - f}$. The resonances of $3-\mathrm{CH}_{3}$ protons in the case of $\mathbf{5 a - f}$ compounds were shifted about $0.3 \mathrm{ppm}$ downfield in comparison with starting compounds 1a-f. The integration of ${ }^{1} \mathrm{H}$ NMR spectra of the newly synthesized 7-methyl-6,7-dihydroquinazolino[3,2-a][1,5]benzodiazepin-13-ones showed the required number of aromatic protons: eight for $\mathbf{5 a}, \mathbf{b}, \mathbf{d}, \mathbf{e}$, thirteen for $\mathbf{5 c , f}$ and seven for compounds 8,9. The new characteristic resonances in ${ }^{13} \mathrm{C}$ NMR spectra in the region of $155.7-158.3 \mathrm{ppm}$ and at about $160 \mathrm{ppm}$ assigned to $\mathrm{C}=\mathrm{N}$ and to 1-CO groups carbon respectively also confirmed the predicted structures of compounds $\mathbf{5 a - f}$.

\section{Theoretical studies}

The most possible reaction mechanism for acylation-cyclization reaction of 5-substituted 3methyl-1,3,4,5-tetrahydro-2H-1,5-benzodiazepin-2-ones 1a-f with 2-sulfinylaminobenzoyl chloride 4 exhibited in Scheme 4.
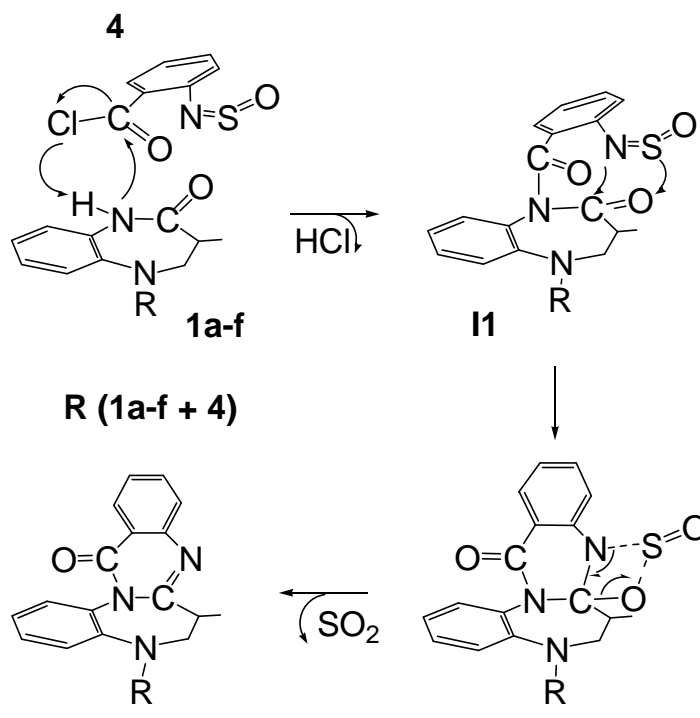

$P(5 a-f)$

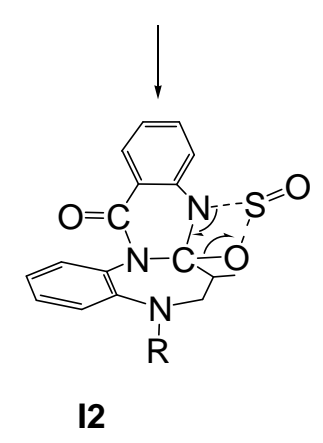

Scheme 4. Possible mechanism for the acylation-cyclization reaction of 5-substituted 3-methyl1,3,4,5-tetrahydro-2H-1,5-benzodiazepin-2-ones 1a-f with 2-sulfinylaminobenzoyl chloride 4. 
In order to confirm this mechanism, Density Functional Theory (DFT) analysis of possible acylation-cyclization reaction pathways was performed by calculation of reaction stationary points along minimal energy path given as IRC. ${ }^{20,21,25-27}$ Theoretical studies on heterocyclization reactions indicated that the activation energies as well as properties of stationary points were in a good agreement with the experimental results if the B3LYP hybrid functional at the DFT was used for the calculation. ${ }^{28-33}$ An attempt to choose basis sets $6-311++G(d, p), 6-31+G(d)$, 6$31 \mathrm{G}(\mathrm{d}, \mathrm{p})$ and $6-31 \mathrm{G}(\mathrm{d})$ for evaluation reactions of heterocyclic systems with heavy atoms revealed that all basis sets provided almost identical results. ${ }^{9,34-37}$ Thus, we chose $6-31+\mathrm{G}(\mathrm{d}, \mathrm{p})$ basis set as the best compromise between speed and accuracy for the investigation of the acylation-cyclization reaction.

The precursors 1e and $\mathbf{4}$ were selected as a model and the detailed reaction mechanism study was carried out using a transition state theory approach..$^{20,21,25,26}$ Additionally the electron density transformation along the reaction minimal energy path was evaluated by calculation of Natural Bond Orbital (NBO) charges and Wiberg bond indexes (BI). ${ }^{38}$

The polarity of reaction conditions should play a very important role in stabilization of different intermediates and transition states. ${ }^{26}$ The acylation-cyclization reaction was modeled in the consideration of DCE solvent to simulate experimental conditions.

Three presumed most probable reaction pathways (I-III) analyzed on the basis of the known experimental investigations dealing with sulfinylamine and carbonyl group interaction and acylation reaction mechanism ${ }^{39}$ for the theoretical study of acylation-cyclization reaction are presented in Scheme 5.

Thus, in reaction pathway (I) the attack of the carbon atom $\mathrm{C}\left(1^{\prime}\right)$ of $\mathbf{4}$ on the $\mathrm{N}(1)$ atom of $\mathbf{1 e}$ proceeds through transition structure $\mathbf{T 1}$ and transforms to intermediate $\mathbf{I 1}$ together with the migration of chloride and hydrogen atoms until $\mathrm{HCl}$ forms. The calculated Gibbs free energies of activation $\left(\Delta \mathrm{G}^{\ddagger}\right)$ for pathway (I) were 41.13 and $32.17 \mathrm{kcal} / \mathrm{mol}$ in the gas phase and in the solvent, respectively. In pathway (II), the initial attack of $\mathrm{N}\left(2^{\prime}\right)$ and $\mathrm{S}\left(2^{\prime}\right)$ atoms of the 2sulfinylamino group of $\mathbf{4}$ on the $\mathrm{C}(2)=\mathrm{O}\left(2^{\prime}\right)$ bond atoms proceeds via transition state T1' leading to intermediate I1'. The $\Delta \mathrm{G}^{\ddagger}$ for pathway (II) were 61.49 and $42.09 \mathrm{kcal} / \mathrm{mol}$ in the gas phase and in the solvent, respectively. In pathway (III), the simultaneous interaction of both reacting centers, $\mathrm{C}\left(1^{\prime}\right)$ and the $\mathrm{N}\left(2^{\prime}\right)$ and $\mathrm{S}\left(2^{\prime}\right)$ atoms of $\mathbf{4}$ with $\mathrm{N}(1)$ and the $\mathrm{C}(2)=\mathrm{O}\left(2^{\prime}\right)$ bond atoms of $\mathbf{1 e}$ accordingly, goes via transition state T1" leading to the formation of the new $\mathrm{N}(1)-\mathrm{C}\left(1^{\prime}\right), \mathrm{C}(2)$ $\mathrm{N}\left(2^{\prime}\right), \mathrm{S}\left(2^{\prime}\right)-\mathrm{O}(2)$ bonds in one step. The calculated $\Delta \mathrm{G}^{\ddagger}$ for pathway (III) were 47.94 and 39.67 $\mathrm{kcal} / \mathrm{mol}$ in the gas phase and in the solvent, respectively. The obtained results indicate that the reaction pathway (I) is the most energy-favorable pathway for initial interaction of chloride 4 with benzodiazepinone 1e. Considering this, we further focused our attention on the detailed description of this reaction pathway. The B3LYP/6-31+G(d,p) calculated geometric parameters of the reaction stationary points: $\mathbf{R}, \mathbf{T}, \mathbf{I}$ and $\mathbf{P}$ for pathway (I) located along the reaction coordinate are presented in Scheme 6. 
The $\Delta \mathrm{G}^{\ddagger}$ of $\mathbf{T}$ activation or $\mathbf{I}$ stabilization were calculated as the difference of free energies between $\mathbf{T}$ and the prereactive complexes ( $\mathbf{R}$ or $\mathbf{I})$ discussed throughout the text and shown in the reaction free-energy profile in Figure 2.

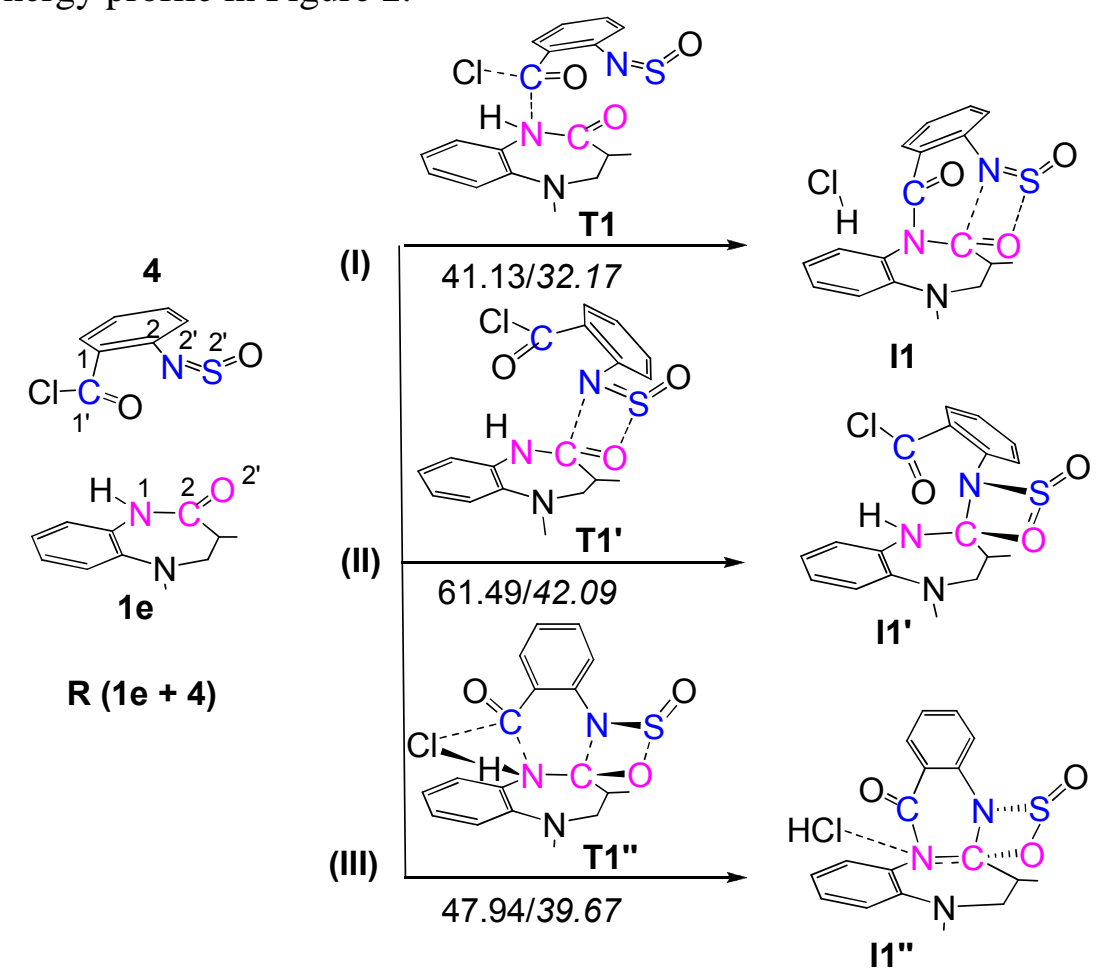

Scheme 5. B3LYP/6-31+G(d,p) calculated possible reaction pathways (I-III) for acylationcyclization reaction of $\mathbf{1 e}$ and $\mathbf{4}$. Activation Gibbs free energies $\left(\Delta \mathrm{G}^{\ddagger}, \mathrm{kcal} / \mathrm{mol}\right)$ for gas phase (regular font) and for solvent phase (italic font) were taken as the difference between $\mathbf{T}$ and $\mathbf{R}$ of free energies.

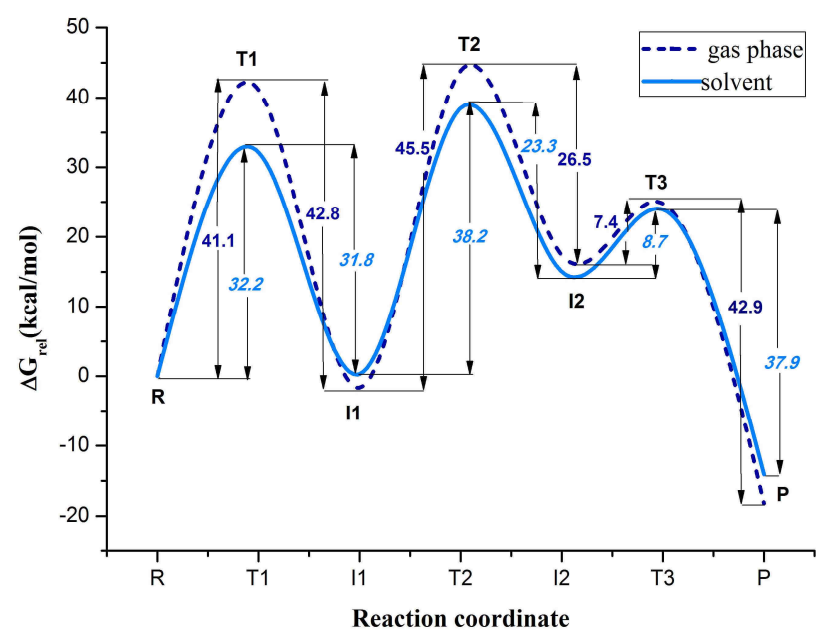

Figure 2. Schematic relative Gibbs free-energy profile for the formation of 5e from $\mathbf{1 e}$ and $\mathbf{4}$ in the gas phase (dashed line) and solvent phase (solid line). $\Delta \mathrm{G}_{\mathrm{rel}}$ of activation and stabilization for gas phase (regular values) and solvent phase (italic values). 
The relative B3LYP/6-31+G(d,p) Gibbs free energy $\left(\Delta \mathrm{G}^{\ddagger}\right.$ (kcal/mol), relative to $\left.\mathbf{R}\right)$ for all stationary points are given in Table S1. (Tables S1-S5 are listed in supplementary information file). The B3LYP/6-31+G(d,p) calculated total energies (E) and Gibbs free energies (G) with the imaginary frequency (vi) modes of transition states are listed in Table S2. The important for acylation-cyclization reaction progress bond distances (BD), Wiberg bond indexes (BI) and the charges on the selected atoms calculated using natural population analysis (NPA) for all stationary points are summarized in Tables S3, S4 and S5.

As shown in Scheme 6, the reaction starts with the interaction of the electrophilic $\mathrm{C}\left(1^{\prime}\right)$ carbon atom of the $\mathrm{C}\left(1^{\prime}\right)=\mathrm{O}\left(1^{\prime}\right)$ group of $\mathbf{4}$ with the $\mathrm{N}(1)$ atom of $\mathbf{1 e}$ under the formation of intermediate I1. As the system moves to transition state T1, significant structural changes occur. Firstly, the chloride atom migrates toward the hydrogen atom of the $\mathrm{N}(1)-\mathrm{H}$ group until the $\mathrm{C}\left(1^{\prime}\right)-\mathrm{Cl}$ bond disruption due to the stabilizing Van der Waals interaction between the $\mathrm{Cl}$ and $\mathrm{H}\left(1^{\prime}\right)$ atoms within a distance of $2.7 \AA$. Secondly, 4 approaches $1 \mathrm{e}$ until the distance between the $\mathrm{C}\left(1^{\prime}\right)$ and $\mathrm{N}(1)$ atoms (BD C (1')-N(1)) shortens to $1.95 \AA$ and the Wiberg bond index (BI C(1')$\mathrm{N}(1)$ ) increases to 0.41 . Simultaneously, the positive charge on the $\mathrm{C}\left(1^{\prime}\right)$ atom in 4 increases progressively from +0.55 in $\mathbf{R}$ to +0.80 in $\mathbf{T 1}$, whereas $\mathrm{N}(1)$ of $\mathbf{1 e}$ becomes more negative ($0.65)$ in $\mathbf{T} 1$ along the same path. This exhibits a weak and highly polarized $\mathrm{C}\left(1^{\prime}\right)-\mathrm{N}(1)$ bond formation at $\mathbf{T} 1$.

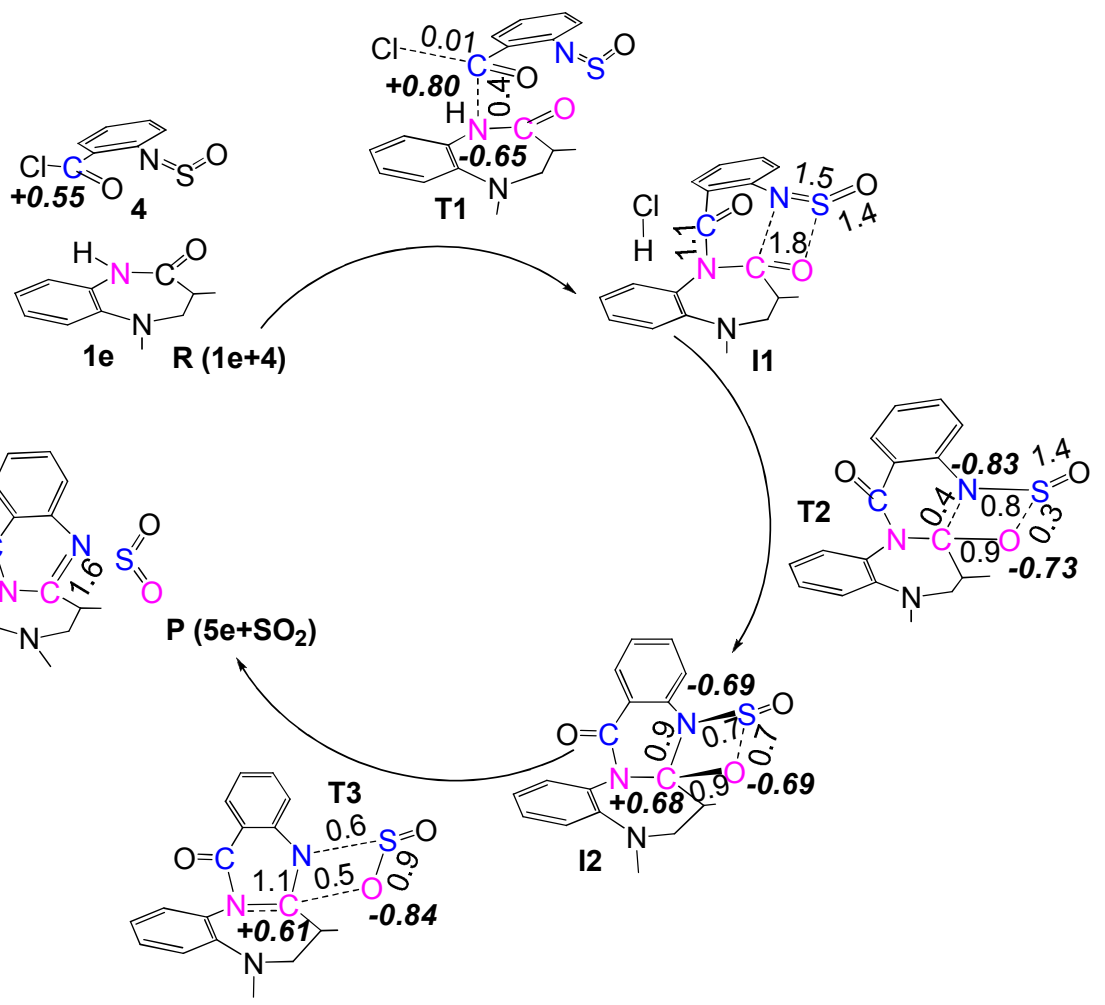

Scheme 6. B3LYP/6-31+G(d,p) calculated geometries of optimized $\mathbf{R}, \mathbf{T}, \mathbf{I}$, and $\mathbf{P}$ for reaction pathway (I) of 1e and $\mathbf{4}$ to 5e. Wiberg bond index (regular values) and NPA charges (bold italic values). 
As the system goes further to intermediate I1, $\mathrm{H}\left(1^{\prime}\right)$ migrates toward chloride until $\mathrm{HCl}$ molecule creation. BD C(1')- $\mathrm{N}(1)$ further shortens to $1.39 \AA$ and $\mathrm{BI} C\left(1^{\prime}\right)-\mathrm{N}(1)$ increases to 1.05. The stabilization energy of $\mathbf{I} \mathbf{1}$ is $31.84 \mathrm{kcal} / \mathrm{mol}$ for the solvent phase. The complete migration of $\mathrm{Cl}$ to $\mathrm{H}\left(1^{\prime}\right)$ and $\mathrm{C}\left(1^{\prime}\right)-\mathrm{N}(1) \sigma$-bond formation is the most significant change from T1 to I1. The transition of I1 via $\mathbf{T} 2$ to $\mathbf{I} 2$ requires activation energy $38.18 \mathrm{kcal} / \mathrm{mol}$ for a solvent. At this step, 4 together with $\mathrm{N}\left(2^{\prime}\right)-\mathrm{S}\left(2^{\prime}\right)=\mathrm{O}\left(2^{\prime}\right)$ moiety migrates towards the $\mathrm{C}(2)=\mathrm{O}\left(2^{\prime}\right)$ bond plane of $1 e$ with the nitrogen $\mathrm{N}\left(2^{\prime}\right)$ atom heading towards $\mathrm{C}(2)$ and the $\mathrm{S}\left(2^{\prime}\right)$ atom heading towards the $\mathrm{O}\left(2^{\prime}\right)$ atom until the system reaches $\mathbf{T 2}$. With this migration, the $\pi$-electrons from $\mathrm{C}(2)=\mathrm{O}\left(2^{\prime}\right)$ of $\mathbf{1 e}$ and $\mathrm{N}\left(2^{\prime}\right)=\mathrm{S}\left(2^{\prime}\right)$ of 4 are used to form new $\mathrm{N}\left(2^{\prime}\right)-\mathrm{C}(2)$ and $\mathrm{S}\left(2^{\prime}\right)-\mathrm{O}\left(2^{\prime}\right) \sigma$ bonds. As a result, the negative charge on the $\mathrm{N}\left(2^{\prime}\right)$ atom of the $\mathrm{N}\left(2^{\prime}\right)=\mathrm{S}\left(2^{\prime}\right)$ bond decreases gradually from -0.83 in $\mathbf{T} 2$ to -0.69 in $\mathbf{I} 2$ and $\mathrm{O}\left(2^{\prime}\right)$ charge of the $\mathrm{C}(2)=\mathrm{O}\left(2^{\prime}\right)$ bond changes from -0.73 in $\mathbf{T} 2$ to -0.69 in $\mathbf{~} \mathbf{2}$. It causes the $\mathrm{N}\left(2^{\prime}\right)-\mathrm{S}\left(2^{\prime}\right)$ bond weakening from $\mathrm{BI} \mathrm{N}\left(2^{\prime}\right)-\mathrm{S}\left(2^{\prime}\right) 1.50$ in $\mathbf{I 1}$ to 0.81 in $\mathbf{T} 2$ and the $\mathrm{C}(2)=\mathrm{O}\left(2^{\prime}\right)$ bond weakening from $\mathrm{BI} \mathrm{C}(2)=\mathrm{O}\left(2^{\prime}\right) 1.75$ to 0.90 , respectively. Simultaneously, the new bonding interactions $\mathrm{N}\left(2^{\prime}\right)---\mathrm{C}(2)$ and $\mathrm{S}\left(2^{\prime}\right)----\mathrm{O}\left(2^{\prime}\right)$ form until the bond index increases to BI N(2')-C(2) 0.36 and BI S(2')-O(2') 0.33 at T2. As the system moves to I2, the $\mathrm{N}\left(2^{\prime}\right)-\mathrm{C}(2)$ and $\mathrm{S}\left(2^{\prime}\right)-\mathrm{O}\left(2^{\prime}\right)$ bonds further strengthen to $\mathrm{BI} \mathrm{N}\left(2^{\prime}\right)-\mathrm{C}(2) 0.96$ and $\mathrm{BI} \mathrm{S}\left(2^{\prime}\right)-\mathrm{O}\left(2^{\prime}\right) 0.72$ respectively, whereas, the $\mathrm{N}\left(2^{\prime}\right)-\mathrm{S}\left(2^{\prime}\right)$ bond further weakens from $\mathrm{BI} \mathrm{N}\left(2^{\prime}\right)-\mathrm{S}\left(2^{\prime}\right) 0.81$ in $\mathbf{T} 2$ to 0.74 for $\mathbf{I} 2$ at this step. The structure of $\mathbf{I} 2$ is analogous to that of $\mathbf{T 2}$ with the stabilization energy 23.29 $\mathrm{kcal} / \mathrm{mol}$ for a solvent. The main structural change of this step is $\mathrm{N}\left(2^{\prime}\right)=\mathrm{S}\left(2^{\prime}\right)$ and $\mathrm{C}(2)=\mathrm{O}\left(2^{\prime}\right)$ bond transformations from $\pi$ - to a $\sigma$-bonding character until the formation of cyclic tetragonal $\sigma$ bonded intermediate complex I2. Starting from I2, the reacting system easily reaches the transition state $\mathbf{T 3}$ leading to final products.

The energy barrier of the third step is $8.68 \mathrm{kcal} / \mathrm{mol}$ for a solvent. The $\mathrm{N}\left(2^{\prime}\right)=\mathrm{S}\left(2^{\prime}\right)$ and $\mathrm{C}(2)=\mathrm{O}\left(2^{\prime}\right)$ bonds disruption with simultaneous $\mathrm{S}\left(2^{\prime}\right)=\mathrm{O}\left(2^{\prime}\right)$ and $\mathrm{C}(2)=\mathrm{N}\left(2^{\prime}\right) \pi$ bonds creation is the main structural change of this step. Starting from $\mathbf{I} 2$ to $\mathbf{T 3}$, the electron density flows to the $\mathrm{O}\left(2^{\prime}\right)$ atom of 1e increasing the negative charge from -0.69 at $\mathbf{I 2}$ to -0.84 at $\mathbf{T 3}$, whereas, the positive charge on the $\mathrm{C}(2)$ atom decreases from +0.68 to +0.61 along the same path. With this charge transfer, the polarization, weakening and lengthening of $\mathrm{C}(2)-\mathrm{O}\left(2^{\prime}\right)$ and $\mathrm{N}\left(2^{\prime}\right)-\mathrm{S}\left(2^{\prime}\right)$ bonds occur. For example, the $\mathrm{C}(2)-\mathrm{O}\left(2^{\prime}\right)$ bond weakens from BI C(2)-O(2') 0.90 at $\mathbf{I} 2$ to $\mathrm{BI} \mathrm{C}(2)-\mathrm{O}\left(2^{\prime}\right)$ 0.47 at $\mathbf{T 3}$ upon bond disruption at $\mathbf{P}$, whereas, $\mathrm{C}(2)=\mathrm{N}\left(2^{\prime}\right)$ bond strengthening occurs from BI C(2)-N(2') 1.08 at $\mathbf{T 3}$ to $\mathrm{BI} \mathrm{C}(2)-\mathrm{N}\left(2^{\prime}\right) 1.59$ at the product 5e along the same path.

The detailed theoretical analysis of the interaction of 3,5-dimethyl-1,3,4,5-tetrahydro- $\mathrm{H}-1,5$ benzodiazepin-2-one (1e) with 2-sulfinylaminobenzoyl chloride (4) showed that the acylationcyclization reaction can be described as sequential three-step process. Firstly, the pre-reactive reactant complex is activated to intermediate with stabilized Van der Waals interaction between $\mathrm{Cl}$ and $\mathrm{H}$ atoms. Secondly, the Van der Waals stabilized intermediate complex transforms to the cyclic tetragonal $\sigma$-bonded intermediate complex with the activation barrier of $38.18 \mathrm{kcal} / \mathrm{mol}$ suggesting that this step along the reaction path is rate limiting. Thirdly, the tetragonal $\sigma$-bonded intermediate transforms into the final product 5,7-dimethyl-6,7-dihydroquinazolino[3,2a][1,5]benzodiazepin-13(5H)-one (5e) and $\mathrm{SO}_{2}$ with the activation barrier of $8.68 \mathrm{kcal} / \mathrm{mol}$. 
During the acylation-cyclization reaction pathway, the transfer of the charge and $\pi$ bond electron density is significant. This suggests the complicated nature of $\sigma$ - and $\pi$-bonding transformations on the reaction path. The solvent influence on reaction rate points out that the solvents effectively lower the energy of reaction barrier and favor the reaction path.

\section{Conclusions}

A simple and efficient method for the preparation of 5-substituted 7-methyl-6,7-dihydroquinazolino[3,2-a][1,5]benzodiazepine-13-ones via a single acylation-cyclization process using readily available 2-sulfinylaminobenzoyl chlorides is described. Operational simplicity and good yields are the salient features of this method. This method may be applicable for the synthesis of libraries of fused polycyclic 1,5-benzodiazepin-2-ones. Furthermore, a detailed theoretical analysis of the acylation-cyclization reaction is described for the first time.

\section{Experimental Section}

\section{Computational details}

The relevant stationary points were fully optimized in the gas phase using DFT method with hybrid density functional B3LYP using 6-31+G(d,p) basis set. Stationary points were further characterized as minima with all real frequencies or as transition states with only one imaginary frequency by computations of harmonic vibrational frequencies at the same theory level as geometry optimization. The connection between the different transition states and reaction intermediates was ensured by intrinsic reaction coordinate calculations. ${ }^{27}$ " $\Delta \mathrm{G}^{\ddagger}$ were calculated as the difference of free energies between transition states and intermediate complexes. Zeropoint energies and thermodynamic parameters at $298 \mathrm{~K}$ and $100 \mathrm{kPa}$ were obtained from harmonic vibrational frequency calculations. In order to account for the solvent effects, the solvation energies were calculated on the gas-phase optimized structures with the self-consistent reaction field method on the basis of the polarized continuum model (PCM). ${ }^{40}$ In this work, single-point energy calculations at the PCM/6-31+G(d,p) level were carried out in DCE solution on the basis of the gas-phase optimized geometries as implemented in Gaussian03. ${ }^{41}$

\section{Experimental details}

Melting points were determined in open capillaries on a MEL-TEMP 1202D apparatus. The IR spectra (potassium bromide) were taken on a Perkin Elmer Spectrum GX FT-IR spectrometer. ${ }^{1} \mathrm{H}$ and ${ }^{13} \mathrm{C}$ NMR spectra were recorded on Bruker Ascend ${ }^{\mathrm{TM}} 400$ at $302 \mathrm{~K}$. Chemical shifts $(\delta)$ are reported relative to tetramethylsilane (TMS) with the solvent reference: $\mathrm{CDCl}_{3}(\delta 7.26 \mathrm{ppm})$, for ${ }^{1} \mathrm{H}$ NMR and $\mathrm{CDCl}_{3}(\delta 77.0 \mathrm{ppm})$, for ${ }^{13} \mathrm{C}$ NMR. The reaction progress and the purity of the compounds were controlled by TLC on a Merck precoated silica gel aluminum roll (60F254) 
with chloroform-ethyl acetate-methanol $(v / v, 14: 7: 1)$ as the eluent. Dry column vacuum chromatography $^{42}$ was performed with silica gel $60(0.015-0.040 \mathrm{~mm}$, Merck). Microanalyses were performed with Thermo Scientific ${ }^{\text {TM }}$ Flash 2000 CHNS/O analyser. The synthesis and NMR spectral data of the starting 5 -acetyl- (1a) ${ }^{43}$ 5-formyl- $(\mathbf{1 b}),{ }^{44}$ 5-benzoyl- $(\mathbf{1 c}),{ }^{19}$ 5-methyl- $(\mathbf{1 e})^{45}$ and 5-benzyl- (1f) ${ }^{46}$ benzodiazepinones were published previously; the newly synthesized 5ethoxycarbonyl compound $\mathbf{1 d}$ is described here.

General procedure for the synthesis of 5-R-7-methyl-6,7-dihydroquinazolino[3,2-a][1,5]benzodiazepin-13(5H)-ones (5a-f, 8 and 9). A suspension of anthranilic acid $(0.82 \mathrm{~g}, 6.0$ mmol) or substituted anthranilic acid $\mathbf{6 , 7}$ and thionyl chloride $(4.3 \mathrm{~mL}, 60 \mathrm{mmol})$ in dry benzene $(60 \mathrm{~mL})$ was refluxed until the reaction mixture became clear $(2-3 \mathrm{~h})$. The solvent was evaporated under vacuum. Then, dry benzene $(30 \mathrm{~mL})$ was added and distilled out. After repeating this procedure twice, the resulting dark oil was dissolved in dry DCE $(10 \mathrm{~mL})$ and added to a dry DCE solution $(60-80 \mathrm{~mL})$ of the appropriate 5-substituted benzodiazepin-2-one 1a-f (4 mmol) with stirring, which contains DIPEA $(1.7 \mathrm{~mL}, 10 \mathrm{mmol})$ and catalytic amount of DMAP. The reaction mixture was stirred at room temperature for 18-24 $\mathrm{h}$ and then diluted with $150 \mathrm{~mL}$ of DCE. The solution washed with $5 \% \mathrm{NaHCO}_{3}$ and water, dried and evaporated to dryness in vacuum. The obtained oily residues were then subjected to a dry column vacuum chromatography (silicagel) using a mixture of DCE and ethyl acetate (3:1) as eluting solvent. After chromatographic purification, the resulting compounds 5a-f, 8 and 9 were recrystallized from dichloromethane-diethyl ether mixture.

5-Acetyl-7-methyl-6,7-dihydroquinazolino[3,2-a][1,5]benzodiazepin-13(5H)-one (5a). Sandy crystals, yield $74 \%, 0.68 \mathrm{~g}, \mathrm{mp} 248-250{ }^{\circ} \mathrm{C}$. IR $\left(\mathrm{KBr}, v_{\max }, \mathrm{cm}^{-1}\right): 1687$ and $1660(\mathrm{C}=\mathrm{O}), 1609$ $(\mathrm{C}=\mathrm{N}) .{ }^{1} \mathrm{H}$ NMR $\left(400 \mathrm{MHz}, \mathrm{CDCl}_{3}\right): \delta_{\mathrm{H}} 1.41\left(3 \mathrm{H}, \mathrm{d},{ }^{3} J_{\mathrm{HH}} 6.5 \mathrm{~Hz}, 3-\mathrm{CH}_{3}\right), 1.84\left(3 \mathrm{H}, \mathrm{s}, \mathrm{COCH}_{3}\right)$, $2.86\left(1 \mathrm{H}, \mathrm{ddq},{ }^{3} J_{\mathrm{HH}} 12.6 \mathrm{~Hz},{ }^{3} J_{\mathrm{HH}} 12.6 \mathrm{~Hz},{ }^{3} J_{\mathrm{HH}} 6.4 \mathrm{~Hz}, 3-\mathrm{CH}\right), 3.42\left(1 \mathrm{H}, \mathrm{dd},{ }^{3} J_{\mathrm{HH}} 5.9 \mathrm{~Hz},{ }^{2} J_{\mathrm{HH}}\right.$ $\left.12.5 \mathrm{~Hz}, 4-\mathrm{CH}_{2}\right), 4.54\left(1 \mathrm{H}, \mathrm{dd},{ }^{3} \mathrm{~J}_{\mathrm{HH}} 12.5 \mathrm{~Hz},{ }^{2} J_{\mathrm{HH}} 12.5 \mathrm{~Hz}, 4-\mathrm{CH}_{2}\right), 7.32-8.29\left(8 \mathrm{H}, \mathrm{m}, \mathrm{CH}_{\text {arom }}\right)$. ${ }^{13} \mathrm{C} \mathrm{NMR}\left(100 \mathrm{MHz}, \mathrm{CDCl}_{3}\right) \delta_{\mathrm{C}} 13.8\left(3-\mathrm{CH}_{3}\right), 22.7\left(\mathrm{COCH}_{3}\right), 36.5(\mathrm{C}-3), 54.6(\mathrm{C}-4), 121.0(\mathrm{C}-$ $\left.1^{\prime}\right), 127.1(2 \mathrm{CH}), 127.8(\mathrm{CH}), 128.7(\mathrm{CH}), 129.0(\mathrm{CH}), 129.3(\mathrm{CH}), 129.9(\mathrm{CH}), 133.8(\mathrm{C}-9 \mathrm{a}$ or C-5a), $134.7(\mathrm{CH}), 136.2$ (C-5a or C9a), 146.9 (C-2'), 155.8 (C-2), 161.0 (1-CO), 170.2 (5- CO); Anal. Calcd. for $\mathrm{C}_{19} \mathrm{H}_{17} \mathrm{~N}_{3} \mathrm{O}_{2}$ (319.36): C, 71.46; H, 5.37; N, 13.16. Found: C, 71.67; H, 5.50; N, $13.00 \%$.

7-Methyl-13-oxo-7,13-dihydroquinazolino[3,2-a][1,5]benzodiazepine-5(6H)-carbaldehyde (5b). Yellowish crystals, yield 53\%, $0.65 \mathrm{~g}, \mathrm{mp} 254-250{ }^{\circ} \mathrm{C} . \mathrm{IR}\left(\mathrm{KBr}, v_{\max }, \mathrm{cm}^{-1}\right): 1687$ and $1667(\mathrm{C}=\mathrm{O}), 1609(\mathrm{C}=\mathrm{N}) .{ }^{1} \mathrm{H}$ NMR $\left(400 \mathrm{MHz}, \mathrm{CDCl}_{3}\right): \delta_{\mathrm{H}} 1.32\left(3 \mathrm{H}, \mathrm{d},{ }^{3} J_{\mathrm{HH}} 6.5 \mathrm{~Hz}, 3-\mathrm{CH}_{3}\right)$, 2.89-3.09 (1H, m, 3-CH), $3.52\left((0.86) 1 \mathrm{H}, \mathrm{dd},{ }^{3} J_{\mathrm{HH}} 5.5 \mathrm{~Hz},{ }^{2} J_{\mathrm{HH}} 12.5 \mathrm{~Hz}, 4-\mathrm{CH}_{2}\right), 3.82$ $\left((0.14) 1 \mathrm{H}, \mathrm{dd},{ }^{3} J_{\mathrm{HH}} 5.5 \mathrm{~Hz},{ }^{2} J_{\mathrm{HH}} 11.7 \mathrm{~Hz}, 4-\mathrm{CH}_{2}\right), 3.97\left((0.14) 1 \mathrm{H}, \mathrm{dd},{ }^{3} J_{\mathrm{HH}} 11.7 \mathrm{~Hz},{ }^{2} J_{\mathrm{HH}} 11.7\right.$ $\left.\mathrm{Hz}, 4-\mathrm{CH}_{2}\right), 4.03\left((0.86) 1 \mathrm{H}, \mathrm{dd},{ }^{3} J_{\mathrm{HH}} 12.5 \mathrm{~Hz},{ }^{2} J_{\mathrm{HH}} 12.5 \mathrm{~Hz}, 4-\mathrm{CH}_{2}\right), 7.44-8.17\left(8 \mathrm{H}, \mathrm{m}, \mathrm{CH}_{\text {arom }}\right)$, $8.23((0.14) 1 \mathrm{H}), \mathrm{s}, \mathrm{COH}), 8.26((0.86) 1 \mathrm{H}, \mathrm{s}, \mathrm{COH}) .{ }^{13} \mathrm{C} \mathrm{NMR}\left(100 \mathrm{MHz}, \mathrm{CDCl}_{3}\right): \delta_{\mathrm{C}} 13.9(3-$ $\left.\mathrm{CH}_{3}\right), 35.3(\mathrm{C}-3), 52.7(\mathrm{C}-4), 120.7\left(\mathrm{C}-1^{\prime}\right), 126.7(\mathrm{CH}), 127.2(\mathrm{CH}), 127.3(\mathrm{CH}), 128.0(2 \mathrm{CH})$, $128.2(\mathrm{CH}), 129.6(\mathrm{CH}), 132.5\left(\mathrm{C}-5 \mathrm{a}\right.$ or C-9a), $134.1\left(\mathrm{C}-9 \mathrm{a}\right.$ or C-5a), $135.0(\mathrm{CH}), 146.4\left(\mathrm{C}-2^{\prime}\right)$, 
156.5 (C-2), 160.1 (1-CO), 162.0, 162.5 (5-CO); Anal. Calcd. for $\mathrm{C}_{18} \mathrm{H}_{15} \mathrm{~N}_{3} \mathrm{O}_{2}$ (305.33): C, 70.81; H, 4.95; N, 13.76. Found: C, 71.02; H, 5.08; N, $13.94 \%$.

5-Benzoyl-7-methyl-6,7-dihydroquinazolino[3,2-a][1,5]benzodiazepin-13(5H)-one

$(\mathbf{5 c})$.

Sandy crystals, yield 69\%, $1.05 \mathrm{~g}, \mathrm{mp} 164-166{ }^{\circ} \mathrm{C}$. IR $\left(\mathrm{KBr}, v_{\max }, \mathrm{cm}^{-1}\right): 1687$ and $1654(\mathrm{C}=\mathrm{O})$, $1609(\mathrm{C}=\mathrm{N}) .{ }^{1} \mathrm{H}$ NMR $\left(400 \mathrm{MHz}, \mathrm{CDCl}_{3}\right): \delta_{\mathrm{H}} 1.51\left(3 \mathrm{H}, \mathrm{d},{ }^{3} J_{\mathrm{HH}} 6.5 \mathrm{~Hz}, 3-\mathrm{CH}_{3}\right), 3.02(1 \mathrm{H}, \mathrm{ddq}$, $\left.{ }^{3} J_{\mathrm{HH}} 12.6 \mathrm{~Hz},{ }^{3} J_{\mathrm{HH}} 12.6 \mathrm{~Hz},{ }^{3} J_{\mathrm{HH}} 6.4 \mathrm{~Hz}, 3-\mathrm{CH}\right), 3.74\left(1 \mathrm{H}, \mathrm{dd},{ }^{3} J_{\mathrm{HH}} 5.7 \mathrm{~Hz},{ }^{2} J_{\mathrm{HH}} 12.6 \mathrm{~Hz}, 4-\right.$ $\left.\mathrm{CH}_{2}\right), 4.38\left(1 \mathrm{H}, \mathrm{dd},{ }^{3} J_{\mathrm{HH}} 12.6 \mathrm{~Hz},{ }^{2} J_{\mathrm{HH}} 12.6 \mathrm{~Hz}, 4-\mathrm{CH}_{2}\right), 6.81-8.37\left(13 \mathrm{H}, \mathrm{m}, \mathrm{CH}_{\text {arom }}\right) ;{ }^{13} \mathrm{C} \mathrm{NMR}$ $\left(100 \mathrm{MHz}, \mathrm{CDCl}_{3}\right): \delta_{\mathrm{C}} 14.0\left(3-\mathrm{CH}_{3}\right), 36.1(\mathrm{C}-3), 56.5(\mathrm{C}-4), 121.1\left(\mathrm{C}-1^{\prime}\right), 127.1(\mathrm{CH}), 127.3$ $(\mathrm{CH}), 127.6(\mathrm{CH}), 127.9(\mathrm{CH}), 128.0(\mathrm{o}-\mathrm{CHPh}), 128.9(\mathrm{CH}), 129.1(\mathrm{~m}-\mathrm{CHPh}), 129.3(\mathrm{CH})$, $129.5(\mathrm{CH}), 130.6(p-\mathrm{CHPh}), 132.8(i-\mathrm{CPh}), 134.2(\mathrm{C}-5 \mathrm{a}$ or $\mathrm{C}-9 \mathrm{a}), 134.8(\mathrm{CH}), 137.4(\mathrm{C}-9 \mathrm{a}$ or C-5a), 146.8 (C-2'), 156.3 (C-2), 161.0 (1-CO), 170.7 (5-CO); Anal. Calcd. for $\mathrm{C}_{24} \mathrm{H}_{19} \mathrm{~N}_{3} \mathrm{O}_{2}$ (381.43): C, 75.57; H, 5.02; N, 11.02. Found: C, 75.72; H, 4.83; N, $10.88 \%$.

Ethyl 7-methyl-13-oxo-7,13-dihydroquinazolino[3,2-a][1,5]benzodiazepine-5(6H)-carboxylate (5d). Yellowish solid, yield 50\%, $0.70 \mathrm{~g}, \mathrm{mp} 196-198{ }^{\circ} \mathrm{C}$. IR $\left(\mathrm{KBr}, v_{\max }, \mathrm{cm}^{-1}\right): 1706$ and $1686(\mathrm{C}=\mathrm{O}), 1609(\mathrm{C}=\mathrm{N}) .{ }^{1} \mathrm{H}$ NMR $\left(400 \mathrm{MHz}, \mathrm{CDCl}_{3}\right): \delta_{\mathrm{H}} 1.09\left(3 \mathrm{H}, \mathrm{br} \mathrm{s}, \mathrm{OCH}_{2} \mathrm{CH}_{3}\right), 1.49(3 \mathrm{H}$, d, $\left.{ }^{3} J_{\mathrm{HH}} 6.5 \mathrm{~Hz}, 3-\mathrm{CH}_{3}\right), 2.84-2.93(1 \mathrm{H}, \mathrm{m}, 3-\mathrm{CH}), 3.59\left(1 \mathrm{H}, \mathrm{dd},{ }^{3} J_{\mathrm{HH}} 5.2 \mathrm{~Hz},{ }^{2} J_{\mathrm{HH}} 11.2 \mathrm{~Hz}, 4-\right.$ $\left.\mathrm{CH}_{2}\right), 3.97\left(1 \mathrm{H}\right.$, br s, $\left.\mathrm{OCH}_{2} \mathrm{CH}_{3}\right), 4.07-4.15\left(1 \mathrm{H}, \mathrm{m}, 4-\mathrm{CH}_{2}\right), 4.20\left(1 \mathrm{H}\right.$, br s, $\left.\mathrm{OCH}_{2} \mathrm{CH}_{3}\right), 7.35-$ $8.31\left(8 \mathrm{H}, \mathrm{m}, \mathrm{CH}_{\text {arom }}\right) .{ }^{13} \mathrm{C} \mathrm{NMR}\left(100 \mathrm{MHz}, \mathrm{CDCl}_{3}\right): \delta_{\mathrm{C}} 13.8\left(3-\mathrm{CH}_{3}\right), 14.3\left(\mathrm{OCH}_{2} \mathrm{CH}_{3}\right), 36.5(\mathrm{C}-$ 3), $56.6(\mathrm{C}-4), 62.0\left(\mathrm{OCH}_{2} \mathrm{CH}_{3}\right), 121.2\left(\mathrm{C}-1^{\prime}\right), 126.9(\mathrm{CH}), 127.1(\mathrm{CH}), 127.6(\mathrm{CH}), 127.7(\mathrm{CH})$, $128.6(\mathrm{CH}), 129.0(\mathrm{CH}), 129.3(\mathrm{CH}), 133.0(\mathrm{C}-5 \mathrm{a}$ or C-9a), $134.5(\mathrm{CH}), 135.1(\mathrm{C}-9 \mathrm{a}$ or C-5a), 146.9 (C-2'), 155.0 (C-2), 156.2 (5-COO), 160.8 (1-CO); Anal. Calcd. for $\mathrm{C}_{20} \mathrm{H}_{19} \mathrm{~N}_{3} \mathrm{O}_{3}$ (349.38): C, 68.75; H, 5.48; N, 12.03. Found: C, 68.50; H, 5.35; N, $11.82 \%$.

5,7-Dimethyl-6,7-dihydroquinazolino[3,2-a][1,5]benzodiazepin-13(5H)-one $\quad(5 e) . \quad$ Sandy crystals, yield 62\%, $0.72 \mathrm{~g}$, mp 109-111 ${ }^{\circ} \mathrm{C}$. IR $\left(\mathrm{KBr}, v_{\max }, \mathrm{cm}^{-1}\right): 1676(\mathrm{C}=\mathrm{O})$ and $1609(\mathrm{C}=\mathrm{N})$. ${ }^{1} \mathrm{H}$ NMR $\left(400 \mathrm{MHz}, \mathrm{CDCl}_{3}\right): \delta_{\mathrm{H}} 1.38\left(3 \mathrm{H}, \mathrm{d},{ }^{3} J_{\mathrm{HH}} 6.4 \mathrm{~Hz}, 3-\mathrm{CH}_{3}\right), 2.72\left(3 \mathrm{H}, \mathrm{s}, 5-\mathrm{CH}_{3}\right), 2.91-$ $3.04\left(2 \mathrm{H}, \mathrm{m}, 3-\mathrm{CH}+4-\mathrm{CH}_{2}\right), 3.26\left(1 \mathrm{H}, \mathrm{dd},{ }^{3} J_{\mathrm{HH}} 9.5 \mathrm{~Hz},{ }^{2} J_{\mathrm{HH}} 11.7 \mathrm{~Hz}, 4-\mathrm{CH}_{2}\right), 7.16-8.32(8 \mathrm{H}$, $\left.\mathrm{m}, \mathrm{CH}_{\text {arom }}\right) .{ }^{13} \mathrm{C} \mathrm{NMR}\left(100 \mathrm{MHz}, \mathrm{CDCl}_{3}\right): \delta_{\mathrm{C}} 14.0\left(3-\mathrm{CH}_{3}\right), 37.1(\mathrm{C}-3), 40.2\left(5-\mathrm{CH}_{3}\right), 66.8(\mathrm{C}-4)$, $119.0(\mathrm{CH}), 121.4\left(\mathrm{C}-1^{\prime}\right), 122.6(\mathrm{CH}), 126.5(\mathrm{CH}), 127.1(\mathrm{CH}), 127.27(\mathrm{CH}), 128.36(\mathrm{CH})$, $129.61(\mathrm{CH}), 129.69$ (C-5a or C-9a), $134.27(\mathrm{CH}), 144.84$ (C-9a or C-5a), $146.85\left(\mathrm{C}-2^{\prime}\right), 158.1$ (C-2), 160.9 (1-CO); Anal. Calcd. for $\mathrm{C}_{18} \mathrm{H}_{17} \mathrm{~N}_{3} \mathrm{O}$ (291.35): C, 72.20; H, 5.88; N, 14.42. Found: C, $72.39 ; \mathrm{H}, 6.06 ; \mathrm{N}, 14.60 \%$.

5-Benzyl-7-methyl-6,7-dihydroquinazolino[3,2-a][1,5]benzodiazepin-13(5H)-one (5f). Sandy solid, yield 53\%, $0.78 \mathrm{~g} \mathrm{mp} \mathrm{68-70}{ }^{\circ} \mathrm{C}$. IR $\left(\mathrm{KBr}, v_{\max }, \mathrm{cm}^{-1}\right): 1686(\mathrm{C}=\mathrm{O}), 1608(\mathrm{C}=\mathrm{N}) .{ }^{1} \mathrm{H}$ NMR $\left(400 \mathrm{MHz}, \mathrm{CDCl}_{3}\right): \delta_{\mathrm{H}} 1.32\left(3 \mathrm{H}, \mathrm{d},{ }^{3} J_{\mathrm{HH}} 6.1 \mathrm{~Hz}, 3-\mathrm{CH}_{3}\right), 2.95-3.03\left(2 \mathrm{H}, \mathrm{m}, 3-\mathrm{CH}+4-\mathrm{CH}_{2}\right), 3.20$ $\left(1 \mathrm{H}, \mathrm{dd},{ }^{3} J_{\mathrm{HH}} 11.5 \mathrm{~Hz},{ }^{3} J_{\mathrm{HH}} 13.5 \mathrm{~Hz}, 4-\mathrm{CH}_{2}\right), 4.00$ and $4.39\left(2 \mathrm{H}, \mathrm{AB}_{\mathrm{q}},{ }^{2} J_{\mathrm{HH}} 10.2 \mathrm{~Hz}, 5-\mathrm{CH}_{2}\right)$, 7.10-8.38 (13H, m, $\left.\mathrm{CH}_{\text {arom }}\right) .{ }^{13} \mathrm{C}$ NMR $\left(100 \mathrm{MHz}, \mathrm{CDCl}_{3}\right): \delta_{\mathrm{C}} 14.0\left(3-\mathrm{CH}_{3}\right), 37.0(\mathrm{C}-3), 56.9(5-$ $\left.\mathrm{CH}_{2}\right), 64.1(\mathrm{C}-4), 120.4(\mathrm{CH}), 121.2\left(\mathrm{C}-1^{\prime}\right), 123.2(\mathrm{CH}), 126.6(p-\mathrm{CHPh}), 127.1(2 \mathrm{CH}), 127.4$ $(\mathrm{CH}), 128.0(o-\mathrm{CHPh}), 128.3(\mathrm{CH}), 128.4(\mathrm{~m}-\mathrm{CHPh}), 129.6(\mathrm{CH}), 130.7(\mathrm{C}-5 \mathrm{a}$ or C-9a), 134.4 $(\mathrm{CH}), 137.3$ (i-CPh), 144.4 (C-9a or C-5a), 146.8 (C-2'), 158.3 (C-2), 161.0 (1-CO) ppm. Anal. 
Calcd. for $\mathrm{C}_{24} \mathrm{H}_{21} \mathrm{~N}_{3} \mathrm{O}$ (367.44): C, 78.45; H, 5.76; N, 11.44. Found: C, 78.23; H, 5.65; N, $11.26 \%$.

\section{5-Acetyl-12-chloro-7-methyl-6,7-dihydroquinazolino[3,2-a][1,5]benzodiazepin-13(5H)-one}

(8). Yellowish crystals, yield 68\%, $0.89 \mathrm{~g}, \mathrm{mp} 264-266^{\circ} \mathrm{C}$. IR $\left(\mathrm{KBr}, v_{\max }, \mathrm{cm}^{-1}\right): 1699$ and 1661 $(\mathrm{C}=\mathrm{O}), 1619(\mathrm{C}=\mathrm{N}) .{ }^{1} \mathrm{H}$ NMR $\left(400 \mathrm{MHz}, \mathrm{CDCl}_{3}\right): \delta_{\mathrm{H}} 1.38\left(3 \mathrm{H}, \mathrm{d},{ }^{3} J_{\mathrm{HH}} 6.5 \mathrm{~Hz}, 3-\mathrm{CH}_{3}\right), 1.86$ $\left(3 \mathrm{H}, \mathrm{s}, \mathrm{COCH}_{3}\right), 2.83\left(1 \mathrm{H}, \mathrm{ddq},{ }^{3} J_{\mathrm{HH}} 12.5 \mathrm{~Hz},{ }^{3} J_{\mathrm{HH}} 12.5 \mathrm{~Hz},{ }^{3} J_{\mathrm{HH}} 6.3 \mathrm{~Hz}, 3-\mathrm{CH}\right), 3.41(1 \mathrm{H}, \mathrm{dd}$, $\left.{ }^{3} J_{\mathrm{HH}} 5.9 \mathrm{~Hz},{ }^{2} J_{\mathrm{HH}} 12.5 \mathrm{~Hz}, 4-\mathrm{CH}_{2}\right), 4.53\left(1 \mathrm{H}, \mathrm{dd},{ }^{3} J_{\mathrm{HH}} 12.5 \mathrm{~Hz},{ }^{2} J_{\mathrm{HH}} 12.5 \mathrm{~Hz}, 4-\mathrm{CH}_{2}\right), 7.31-7.68$ $\left(7 \mathrm{H}, \mathrm{m}, \mathrm{CH}_{\text {arom }}\right) .{ }^{13} \mathrm{C} \mathrm{NMR}\left(100 \mathrm{MHz}, \mathrm{CDCl}_{3}\right): \delta_{\mathrm{C}} 13.6\left(3-\mathrm{CH}_{3}\right), 22.8\left(\mathrm{COCH}_{3}\right), 36.5(\mathrm{C}-3), 54.4$ $(\mathrm{C}-4), 118.2\left(\mathrm{C}-1^{\prime}\right), 127.1(\mathrm{CH}), 128.7(\mathrm{CH}), 129.9(\mathrm{CH}), 129.5(\mathrm{CH}), 129.0(\mathrm{CH}), 130.0(\mathrm{CH})$, $134.0(\mathrm{CH}), 133.6$ (C-9a or C-5a), 134.5 (C-6'), 136.1 (C-5a or C-9a), 149.3 (C-2'), 156.6 (C-2), 159.1 (1-CO), 170.3 (5-CO); Anal. Calcd. for $\mathrm{C}_{19} \mathrm{H}_{16} \mathrm{ClN}_{3} \mathrm{O}_{2}$ (353.80): C, 64.50; H, 4.56; N, 11.88. Found: C, 64.29; H, 4.64; N, $11.80 \%$.

\section{5-Acetyl-11-bromo-7-methyl-6,7-dihydroquinazolino[3,2-a][1,5]benzodiazepin-13(5H)-one} (9). Yellowish crystals, yield 51\%, $0.93 \mathrm{~g}, \mathrm{mp} 286-289^{\circ} \mathrm{C}$. IR $\left(\mathrm{KBr}, v_{\max }, \mathrm{cm}^{-1}\right): 1686$ and 1656 $(\mathrm{C}=\mathrm{O}), 1611(\mathrm{C}=\mathrm{N}) .{ }^{1} \mathrm{H}$ NMR $\left(400 \mathrm{MHz}, \mathrm{CDCl}_{3}\right): \delta_{\mathrm{H}} 1.39\left(3 \mathrm{H}, \mathrm{d},{ }^{3} J_{\mathrm{HH}} 6.5 \mathrm{~Hz}, 3-\mathrm{CH}_{3}\right), 1.84$ $\left(3 \mathrm{H}, \mathrm{s}, \mathrm{COCH}_{3}\right), 2.79-2.90(1 \mathrm{H}, \mathrm{m}, 3-\mathrm{CH}), 3.41\left(1 \mathrm{H}, \mathrm{dd},{ }^{3} J_{\mathrm{HH}} 5.5 \mathrm{~Hz},{ }^{2} J_{\mathrm{HH}} 12.4 \mathrm{~Hz}, 4-\mathrm{CH}_{2}\right), 4.54$ $\left(1 \mathrm{H}, \mathrm{dd},{ }^{3} J_{\mathrm{HH}} 12.4 \mathrm{~Hz},{ }^{2} J_{\mathrm{HH}} 12.4 \mathrm{~Hz}, 4-\mathrm{CH}_{2}\right), 7.33-8.40\left(7 \mathrm{H}, \mathrm{m}, \mathrm{CH}_{\text {arom }}\right) .{ }^{13} \mathrm{C} \mathrm{NMR}(100 \mathrm{MHz}$, $\left.\mathrm{CDCl}_{3}\right): \delta_{\mathrm{H}} 13.8\left(3-\mathrm{CH}_{3}\right), 22.7\left(\mathrm{COCH}_{3}\right), 36.6(\mathrm{C}-3), 54.5(\mathrm{C}-4), 120.6\left(\mathrm{C}-5^{\prime}\right), 122.4\left(\mathrm{C}-1^{\prime}\right)$, $128.8(\mathrm{CH}), 129.1(\mathrm{CH}), 129.2(\mathrm{CH}), 129.6(\mathrm{CH}), 129.6(\mathrm{CH}), 130.2(\mathrm{CH}), 133.5(\mathrm{C}-9 \mathrm{a}$ or 5a), 136.1 (C-5a or C-9a), 137.9 CH), 145.8 (C-2'), 156.3 (C-2), 159.9 (1-CO), 170.2 (5-CO); Anal. Calcd. for $\mathrm{C}_{19} \mathrm{H}_{16} \mathrm{BrN}_{3} \mathrm{O}_{2}$ (456.38): C, 57.30; H, 4.05; N, 10.55. Found: C, 57.49; H, 4.20; N, $10.37 \%$.

Ethyl 3-methyl-4-oxo-2,3,4,5-tetrahydro-1 $H$-1,5-benzodiazepine-1-carboxylate (1d). Compound 1d was obtained according to the procedure described ${ }^{18}$ from 3-methyl-1,3,4,5tetrahydro- $2 H$-1,5-benzodiazepin-2-one ${ }^{43}(3.6 \mathrm{~g}, 20 \mathrm{mmol})$, triethylamine $(2.8 \mathrm{~mL}, 20 \mathrm{mmol})$ and ethyl chloroformate $(2.1 \mathrm{~mL}, 22 \mathrm{mmol})$ in dry THF. Crystallization from ethyl acetatediethyl ether gave 1d $(4.1 \mathrm{~g}, 86 \%)$, mp 101-103 ${ }^{\circ} \mathrm{C}$. IR (KBr, $\left.v_{\max }, \mathrm{cm}^{-1}\right): 3187$ and $3124(\mathrm{NH})$, 1703 and $1668(\mathrm{C}=\mathrm{O}) .{ }^{1} \mathrm{H}$ NMR $\left(400 \mathrm{MHz}, \mathrm{CDCl}_{3}\right): \delta_{\mathrm{H}} 1.13\left(3 \mathrm{H}, \mathrm{d},{ }^{3} J_{\mathrm{HH}} 6.6 \mathrm{~Hz}, 3-\mathrm{CH}_{3}\right), 1.11-$ $1.42\left(3 \mathrm{H}, \mathrm{br} \mathrm{m}, \mathrm{OCH}_{2} \mathrm{CH}_{3}\right), 2.78\left(1 \mathrm{H}, \mathrm{pd},{ }^{3} J_{\mathrm{HH}} 6.6 \mathrm{~Hz},{ }^{3} J_{\mathrm{HH}} 13.0 \mathrm{~Hz}, 3-\mathrm{CH}\right), 3.73\left(1 \mathrm{H}, \mathrm{dd},{ }^{3} J_{\mathrm{HH}}\right.$ $\left.6.6 \mathrm{~Hz},{ }^{2} J_{\mathrm{HH}} 12.3 \mathrm{~Hz}, 4-\mathrm{CH}_{2}\right), 3.95-4.35\left(3 \mathrm{H}\right.$, br m, 4- $\left.\mathrm{CH}_{2}+\mathrm{OCH}_{2} \mathrm{CH}_{3}\right), 7.06-7.41(4 \mathrm{H}, \mathrm{m}$, $\left.\mathrm{CH}_{\text {arom }}\right), 8.16((0.26) 1 \mathrm{H}, \mathrm{s}, \mathrm{NH}), 8.35((0.74) 1 \mathrm{H}, \mathrm{s}, \mathrm{NH}) .{ }^{13} \mathrm{C} \mathrm{NMR}\left(100 \mathrm{MHz}, \mathrm{CDCl}_{3}\right): \delta_{\mathrm{C}} 12.7$ $\left(3-\mathrm{CH}_{3}\right), 14.4\left(\mathrm{OCH}_{2} \mathrm{CH}_{3}\right), 35.5(\mathrm{C}-3), 55.9(\mathrm{C}-4), 62.1\left(\mathrm{OCH}_{2} \mathrm{CH}_{3}\right), 122.7(\mathrm{C}-9), 125.7(\mathrm{C}-7)$, 128.0 (C-6), 129.7 (C-8), 133.3 (C-5a), 134.7 (C-9a), 155.0 (COO), 175.21 (C-2); Anal. Calcd. for $\mathrm{C}_{13} \mathrm{H}_{16} \mathrm{~N}_{2} \mathrm{O}_{3}$ (220.27): C, 62.89; H, 6.50; N, 11.28. Found: C, 63.01; H, 6.41; N, $11.49 \%$.

\section{Acknowledgements}

The authors are grateful to the Digital Science and Computing Center at Vilnius University for computational facilities. 


\section{Supplementary Material}

Copies of IR, ${ }^{1} \mathrm{H},{ }^{13} \mathrm{C}$ and NMR spectra and some computational data associated with this work are available as supplementary information in separate file.

\section{References}

1. Archer, G. A.; Sternbach, L. H. Chem. Rev. 1968, 68, 747. http://dx.doi.org/10.1021/cr60256a004

2. Rogowaski, M. A.; Porter, R. J. Pharm. Rev. 1990, 42, 223.

3. Smith, R. H.; Jorgensen, W. L.; Tirado-Rives, J.; Lamb, M. L.; Janssen, P. A. J.; Michejda, C. J.; Kroeger Smith, M. B. J. Med. Chem. 1998, 41, 5272.

4. Sternbach, H. J. Med. Chem. 1979, 22, 1. http://dx.doi.org/10.1021/jm00187a001

5. Ambrogi, V.; Grandolini, G.; Perioli, L.; Giusti, L.; Lucacchini, A.; Martini, C. Eur. J. Med. Chem. 1995, 30, 429. http://dx.doi.org/10.1016/0223-5234(96)88253-5

6. Chimirri, A.; Gitto, R.; Grasso, S.; Monforte, A. M.; Romeo, G.; Zappala, M. Heterocycles 1993, 36, 865.

http://dx.doi.org/10.3987/REV-92-442

7. Kosychova, L.; Stumbreviciute, Z.; Pleckaitiene, L.; Janciene, R.; Puodziunaite, B. D. Chem. Heterocycl. Compd, 2004, 40, 811. http://dx.doi.org/10.1023/B:COHC.0000040781.41929.9c

8. Janciene, R.; Stumbreviciute, Z.; Podeniene, D.; Puodziunaite, B. D. J. Heterocycl. Chem. 2006, $43,979$. http://dx.doi.org/10.1002/jhet.5570430424

9. Janciene, R.; Vektariene, A.; Stumbreviciute, Z.; Puodziunaite, B. Monatsh. Chem. 2011, $142,609$. http://dx.doi.org/10.1007/s00706-011-0496-4

10. Kosychova, L.; Pleckaitiene, L.; Staniulyte, Z.; Janciene, R.; Palaima, A.; Puodziunaite, B. D. Arkivoc 2006, (xiii), 158. http://dx.doi.org/10.3998/ark.5550190.0007.d16

11. Janciene, R.; Stumbreviciute, Z.; Vektariene, A.; Kosychova, L.; Klimavicius, A.; Palaima, A.; Puodziunaite, B. J. Heterocycl. Chem. 2009, 46, 1339. http://dx.doi.org/10.1002/jhet.226

12. Kosychova, L.; Stumbreviciute, Z.; Janciene, R.; Staniulyte, Z.; Puodziunaite, B. D. Arkivoc 2011, $(x i), 82$.

http://dx.doi.org/10.3998/ark.5550190.0012.b08 
13. El-Sayed, A. M.; Abdel-Ghany, H.; El-Saghier, A. M. M. Synth. Commun. 1999, 29, 3561. http://dx.doi.org/10.1080/00397919908085990

14. Yuskovets, V. N.; Ivin, B. A. Russ. J. Gen. Chem. 2007, 77, 2162. http://dx.doi.org/10.1134/S1070363207120146

$\begin{array}{llllllll}\text { 15. Mhaske, S. } & \text { B.; } & \text { Argade, } & \text { N. } & \text { P. } & \text { Tetrahedron } & \text { 2006, } & 62,\end{array}$ http://dx.doi.org/10.1016/j.tet.2006.07.098

16. Al-Said, N. H.; Shawakfeh, K. Q.; Ibrahim, M. I.; Tayyem, S. H. Arkivoc 2010, (ix), 282. http://dx.doi.org/10.3998/ark.5550190.0011.926

17. Taher, D.; Ishtaiwi, Z. N.; Al-Said, N. H. Arkivoc 2008, (xvi), 154. http://dx.doi.org/10.3998/ark.5550190.0009.g15

18. Janciene, R.; Mikulskiene, G.; Javorskis, T.; Vektariene, A.; Vektaris, G.; Kosychova, L. J. Heterocycl. Chem. 2015, 52, 243.

http://dx.doi.org/10.1002/jhet.2038

19. Janciene, R.; Vektariene, A.; Mikulskiene, G.; Javorskis, T.; Vektaris, G.; Klimavicius, A. Arkivoc 2013, (iv), 57.

http://dx.doi.org/10.3998/ark.5550190.p008.073

20. Truhlar, D. G.; Garrett, B. C.; Klippenstein, S. J. J. Phys. Chem. 1996, 100, 12771. http://dx.doi.org/10.1021/jp953748q

$\begin{array}{llllllll}\text { 21. Vektariene, A.; Vektaris, } & \text { G. } \quad \text { Z. Naturforsch. } & B, & \mathbf{2 0 1 1}, & 66, & 850 .\end{array}$ http://dx.doi.org/10.5560/ZNB.2011.66b0850

22. Davies, S. G.; Ling, K. B.; Roberts, P. M.; Russell, A. J.; Thomson, J. E.; Woods, P. A. Tetrahedron 2010, 66, 6806.

23. Garin, J.; Merino, P.; Orduna, J.; Tejero, T.; Uried, S. Tetrahedron Lett. 1991, 32, 3263. http://dx.doi.org/10.1016/S0040-4039(00)79739-5

24. Wang, H.; Ganesan, A. Tetrahedron Lett. 1998, 39, 9097. http://dx.doi.org/10.1016/S0040-4039(98)02004-8

25. Sousa, F.; Fernandes, P. E.; Ramos, M. J. J. Phys. Chem. A. 2007, 111, 10439. http://dx.doi.org/10.1021/jp0734474

26. Vektariene, A. J. Phys. Chem A. 2013, 117, 8449. http://dx.doi.org/10.1021/jp402257u

27. Fukui, K. Acc. Chem. Res. 1981, 14, 363. http://dx.doi.org/10.1021/ar00072a001

28. Becke, A. D. J. Chem. Phys. 1993, 98, 5648. http://dx.doi.org/10.1063/1.464913

29. Lee, C.; Yang, W.; Parr, R. G. Phys. Rev. B. 1988, 37, 785. http://dx.doi.org/10.1103/PhysRevB.37.785

30. Morgado, C. C.; McNamara, J. P.; Hillier, I. H.; Burton, N. A.; Vincent, M. A. J. Chem. Theory. Comput. 2007, 3, 1656.

http://dx.doi.org/10.1021/ct700072a 
31. Vektariene, A.; Vektaris, G.; Svoboda, J. Arkivoc 2009, (vii), 311. http://dx.doi.org/10.3998/ark.5550190.0010.730

32. Vektariene, A.; Vektaris, G.; Rankin, D. W. H. Heteroat. Chem. 2007, 18, 695. http://dx.doi.org/10.1002/hc.20378

33. Vektariene, A.; Vektaris, G. Heteroat. Chem. 2004, 15, 263. http://dx.doi.org/10.1002/hc.20015

$\begin{array}{llllllll}\text { 34. Choe, S. J. Bull. Korean } & \text { Chem. Soc. } & \text { 2012, }\end{array}$ http://dx.doi.org/10.5012/bkcs.2012.33.9.2861

35. Carlson, H. A.; Nguyen, T. B.; Orozco, M.; Jorgensen, W. L. J. Comput. Chem. 2004, 14, 1240. http://dx.doi.org/10.1002/jcc.540141013

36. Vektariene, A.; Vektaris, G. Arkivoc 2006, $\quad$ (xvi), 23. http://dx.doi.org/10.3998/ark.5550190.0007.g03

37. Ledesma, A. E.; Contreras, C.; Svoboda, J.; Vektariene, A.; Brandán, S. A. J. Mol. Struct. 2010, 967, 159; 2014, 1063, 356.

http://dx.doi.org/10.1016/j.molstruc.2014.01.087

38. Reed, A. E.; Curtiss, L. A.; Weinhold, F. Chem. Rev. 1988, 88, 899. http://dx.doi.org/10.1021/cr00088a005

39. Carey, F. A.; Sundberg, R. J. Advanced Organic Chemistry, Part A: Structure and Mechanisms. Springer, 2008, 485.

40. Barone, V.; Cossi, M.; Tomasi, J. J. Comput. Chem. 1998, 19, 404. http://doi: 10.1002/(SICI)1096-987X(199803)19:4<404:AID-JCC3>3.0.CO;2-W

41. Frisch, M. J.; Trucks, G. W.; Schlegel, H. B.; Scuseria, G. E.; Robb, M. A.; Cheeseman, J. R.; Montgomery Jr, J. A.; Vreven, T.; Kudin, K. N.; Burant, J. C.; Millam, J. M.; Iyengar, S. S.; Tomasi, J.; Barone, V.; Mennucci, B.; Cossi, M.; Scalmani, G.; Rega, N.; Petersson, G. A.; Nakatsuji, H.; Hada, M.; Ehara, M.; Toyota, K.; Fukuda, R.; Hasegawa, J.; Ishida, M.; Nakajima, T.; Honda, Y.; Kitao, O.; Nakai, H.; Klene, M.; Li, X.; Knox, J. E.; Hratchian, H. P.; Cross, J. B.; Bakken, V.; Adamo, C.; Jaramillo, J.; Gomperts, R.; Stratmann, R. E.; Yazyev, O.; Austin, A. J.; Cammi, R.; Pomelli, C. ; Ochterski, J. W.; Ayala, P. Y.; Morokuma, K.; Voth, G. A.; Salvador, P.; Dannenberg, J. J., Zakrzewski, V. G.; Dapprich, S.; Daniels, A. D.; Strain, M. C.; Farkas, O.; Malick, D. K.; Rabuck, A. D.; Raghavachari, K.; Foresman, J. B.; Ortiz, J. V.; Cui, Q.; Baboul, A. G.; Clifford, S.; Cioslowski, J.; Stefanov, B. B.; Liu, G.; Liashenko, A.; Piskorz, P.; Komaromi, I.; Martin, R. L.; Fox, D. J.; Keith, T.; Al-Laham, M. A.; Peng, C. Y.; Nanayakkara, A.; Challacombe, M.; Gill, P. M. W.; Johnson, B.; Chen, W.; Wong, M. W.; Gonzalez, C.; Pople, J. A. Gaussian03, revision C 02, Gaussian, Inc., Wallingford, CT, 2004.

42. Pedersen, D. S.; Rosenbohm, C. Synthesis 2001, 16, 2431 http://dx.doi.org/10.1055/s-2001-18722

43. Puodzhunaite, B. A.; Yanchiene, R. A.; Talaikite, Z. A.; Zaks, A. C.; Rabotnikov, Yu, M.; Uzachev, E. A. Khim-Farm. Zh. 1985, 19, 1195. Chem. Abstr. 1986, 105, 133861g. 
44. Puodzhyunaite, B. A.; Yanchene, R. A.; Stumbryavichyute, Z. A. Chem. Heterocycl. Compd. 1988, 24, 786.

http://dx.doi.org/10.1007/BF00633177

45. Aversa, M. C.; Giannetto, P.; Romeo, G.; Ficarra, P.; Vigorita, M. G. Org. Magn. Reson. 1981, 15, 394.

http://dx.doi.org/10.1002/mrc.1270150414

46. Puodžiūnaite, B.; Kosychova, L.; Jančienè, R.; Stumbrevičiūtè, Z. Monatsh. Chem. 1997, $128,1275$.

http://dx.doi.org/10.1007/BF00807260 